Supporting Information for:

\title{
Stable Tetravalent Phosphonium Enolate Zwitterions
}

\author{
Xue-Feng Zhu, Christopher E. Henry, and Ohyun Kwon* \\ Department of Chemistry and Biochemistry, University of California, Los Angeles, California \\ 90095-1569, USA
}

\section{Contents}

General Information $\quad$ S2

Synthetic Procedures and Spectral Data for Zwitterions $1 \quad$ S3

$\begin{array}{ll}\text { - Zwitterion 1a } & \text { S3 }\end{array}$

$\begin{array}{ll}\text { - Zwitterion 1b } & \text { S4 }\end{array}$

- Zwitterion 1c $\quad$ S4

- Zwitterion 1d S5

- Zwitterion 1e S6

- Zwitterion 1f $\quad$ S6

$\begin{array}{ll}\text { - Zwitterion 19 } & \text { S7 }\end{array}$

Formation of a Trace Amount of Dioxane S1 and its Mechanistic Implications $\quad$ S8

${ }^{1} \mathrm{H},{ }^{13} \mathrm{C}$, and ${ }^{31} \mathrm{P}$ NMR Spectra of New Compounds $\quad$ S10

$\begin{array}{ll}\text { ORTEP Representations of Zwitterions } 1 & \text { S17 }\end{array}$

$\begin{array}{lr}\text { - Zwitterion 1a } & \text { S17 }\end{array}$

$\begin{array}{ll}\text { - Zwitterion 1b } & \text { S18 }\end{array}$

$\begin{array}{lr}- \text { Zwitterion 1f } & \text { S19 }\end{array}$ 


\section{General Information}

Unless otherwise noted, reactions were performed under an argon atmosphere and under anhydrous conditions. THF was distilled over sodium/benzophenone ketyl and benzene was distilled from calcium hydride. The following starting materials were purchased from commercial sources and were used as described:

\begin{tabular}{|l|l|l|l|}
\hline Compound & Source & Catalogue \# & Treatment \\
\hline Dimethyl acetylenedicarboxylate & Aldrich & $\mathrm{D} 138401$ & Distilled $\left(95-98{ }^{\circ} \mathrm{C}, 19 \mathrm{mmHg}\right)$ \\
\hline Dimethylphenylphosphine & Strem & $15-1400$ & Used as received \\
\hline Methyl 2-butynoate & Acros & 22349 & Distilled $\left(80-85^{\circ} \mathrm{C}, 85 \mathrm{mmHg}\right)$ \\
\hline Methyldiphenylphosphine & Aldrich & 244902 & Used as received \\
\hline Methyl phenylpropiolate & Aldrich & 543195 & Distilled $\left(108-110^{\circ} \mathrm{C}, 2 \mathrm{mmHg}\right)$ \\
\hline Methyl propiolate & Aldrich & 171859 & $\begin{array}{l}\text { Distilled }\left(100-101{ }^{\circ} \mathrm{C},\right. \\
\text { mmHg) }\end{array}$ \\
\hline 4-pyridinecarboxaldehyde & Aldrich & P62402 & Distilled (77-78 $\left.{ }^{\circ} \mathrm{C}, 12 \mathrm{mmHg}\right)$ \\
\hline Tri- $n$-butylphosphine & Aldrich & T49484 & Used as received \\
\hline Trimethylphosphine & Aldrich & 323322 & Used as received \\
\hline
\end{tabular}

IR spectra were recorded on a Perkin-Elmer Pargon 1600 FT-IR spectrometer. NMR spectra were obtained on Bruker Avance-500, ARX-500, or ARX-400 instruments and calibrated using residual $\mathrm{CHCl}_{3}$ as the internal reference (7.26 and $77.0 \mathrm{ppm}$ for ${ }^{1} \mathrm{H}$ and ${ }^{13} \mathrm{C} \mathrm{NMR}$ spectra, respectively). Data for ${ }^{1} \mathrm{H}$ NMR spectra are reported as follows: chemical shift ( $\left.\delta \mathrm{ppm}\right)$, multiplicity, coupling constant $(\mathrm{Hz})$, and integration. Data for ${ }^{13} \mathrm{C}$ NMR spectra are reported in terms of chemical shift, multiplicities, and coupling constants $(\mathrm{Hz})$ in the case of $J_{\mathrm{CP}}$ coupling. Data for ${ }^{31} \mathrm{P}$ NMR spectra are reported in terms of chemical shift. The following abbreviations are used to explain the multiplicities: $\mathrm{s}=\operatorname{singlet} ; \mathrm{d}=$ doublet; $\mathrm{t}=$ triplet; $\mathrm{q}=$ quartet; $\mathrm{m}=$ multiplet; br = broad; app = apparent. Mass spectra were obtained after matrix-assisted laser desorption/ionization (MALDI) on an Applied Biosystems Voyager-DE STR [matrix: dihydroxybenzoic acid (DHB] operated in reflector mode with external calibration at an accelerating potential of $20 \mathrm{kV}$. 


\section{Synthetic Procedures and Spectral Data for Zwitterions 1}

Several methyl propiolates bearing various terminal substituents were reacted with 4pyridinecarboxaldehyde and tertiary phosphine to yield stable crystalline phosphonium enolate zwitterions as major reaction products. The synthetic procedure and spectral data for each zwitterion are described.

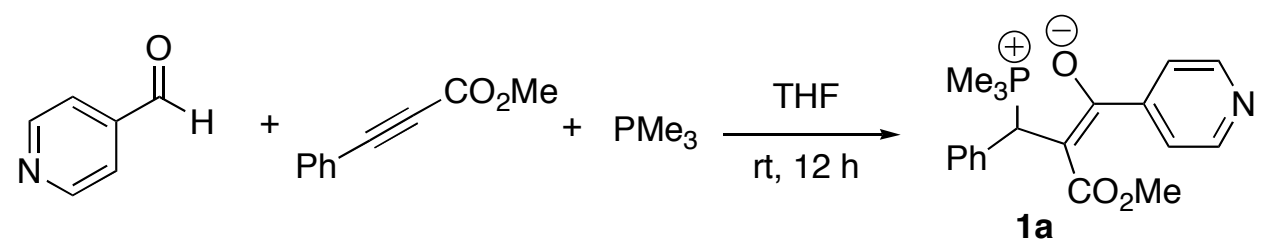

THF (10 mL), 4-pyridinecarboxaldehyde ( $286 \mu \mathrm{L}, 3.0 \mathrm{mmol})$, methyl phenylpropiolate $(89 \mu \mathrm{L}$, $1.0 \mathrm{mmol})$, and trimethylphosphine $(100 \mu \mathrm{L}, 1.0 \mathrm{mmol})$ were added by syringe sequentially to a flame-dried $25-\mathrm{mL}$ round-bottom flask under argon. Immediately after addition of the phosphine, the solution changed color to dark red. The reaction was stirred at room temperature for $12 \mathrm{~h}$ and monitored by TLC $\left[\mathbf{1 a :} R_{\mathrm{f}}(\mathrm{EtOAc})=0.0 ; R_{\mathrm{f}}\left(10 \% \mathrm{MeOH}\right.\right.$ in $\left.\left.\mathrm{CH}_{2} \mathrm{Cl}_{2}\right)<0.05\right]$. The mixture was concentrated and subjected to FCC, first with EtOAc to elute 4-pyridinecarboxaldehyde and then with a gradient of $\mathrm{MeOH}(10-50 \%)$ in $\mathrm{CH}_{2} \mathrm{Cl}_{2}$ to elute 1a, which was collected as a red oil (285 $\mathrm{mg}, 83 \%)$. The product was recrystalized in 1:1:1 toluene:EtOAc:cyclohexane to yield crystals suitable for X-ray crystallography. Upon heating, 1a began to turn brown at $130{ }^{\circ} \mathrm{C}$ and rapidly melted and boiled with extensive decomposition at $210{ }^{\circ} \mathrm{C}$. IR (neat) $v_{\max } 2986,1736,1505$, $1483 \mathrm{~cm}^{-1}$; ${ }^{1} \mathrm{H}$ NMR (500 MHz, $\left.\mathrm{CDCl}_{3}\right) \delta 8.54(\mathrm{dd}, J=4.4,1.4 \mathrm{~Hz}, 2 \mathrm{H}), 7.40-7.39$ (m, 2H), 7.34-7.31 (m, 2H), 7.30-7.28 (m, 1H), 7.25 (dm, $J=5.0 \mathrm{~Hz} 2 \mathrm{H}), 4.50$ (d, $J=13.0 \mathrm{~Hz}, 1 \mathrm{H}), 3.30$ (s, 3H), $1.73(\mathrm{~d}, J=12.5 \mathrm{~Hz}, 9 \mathrm{H}) ;{ }^{13} \mathrm{C} \mathrm{NMR}\left(125 \mathrm{MHz}, \mathrm{CDCl}_{3}\right) \delta 180.2,168.6\left(\mathrm{~d}, J_{\mathrm{CP}}=12.0\right.$ $\mathrm{Hz}), 151.9,149.0(2 \mathrm{C}), 136.3\left(\mathrm{~d}, J_{\mathrm{CP}}=4.1 \mathrm{~Hz}\right), 129.3\left(\mathrm{~d}, J_{\mathrm{CP}}=5.9 \mathrm{~Hz}, 2 \mathrm{C}\right), 128.9\left(\mathrm{~d}, J_{\mathrm{CP}}=3.0\right.$ $\mathrm{Hz}, 2 \mathrm{C}), 128.0\left(\mathrm{~d}, J_{\mathrm{CP}}=3.9 \mathrm{~Hz}\right), 121.7(2 \mathrm{C}), 94.3,49.8,45.5\left(\mathrm{~d}, J_{\mathrm{CP}}=61.3 \mathrm{~Hz}\right), 13.6\left(\mathrm{~d}, J_{\mathrm{CP}}=\right.$ $61.3 \mathrm{~Hz}, 3 \mathrm{C}$ ); ${ }^{31} \mathrm{P}$ NMR (202 MHz, $\mathrm{CDCl}_{3}$ ) $\delta 16.0$; MS (MALDI) calcd for $\mathrm{C}_{19} \mathrm{H}_{23} \mathrm{NO}_{3} \mathrm{P}[\mathrm{M}+$ $\mathrm{H}]^{+} 344.14$, found 344.16 .

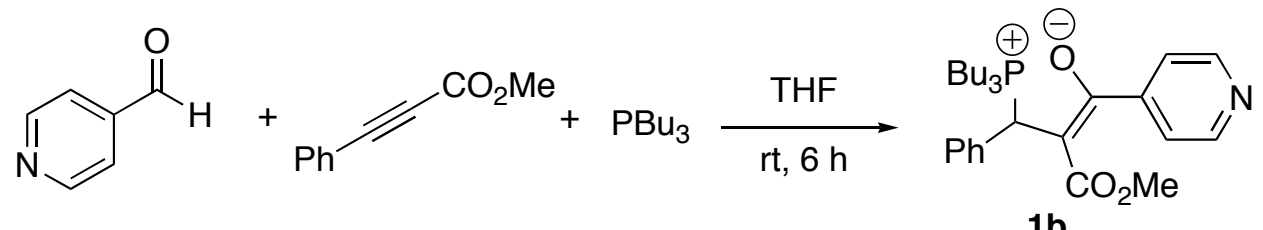

THF $(10 \mathrm{~mL})$ and 4-pyridinecarboxaldehyde $(286 \mu \mathrm{L}, 3.0 \mathrm{mmol})$ were added by syringe to a 
flame-dried 25-mL round-bottom flask. Methyl phenylpropiolate (160 mg, $1.0 \mathrm{mmol}$ ) was weighed in a $1-\mathrm{mL}$ syringe and added. Tri- $n$-butylphosphine $(250 \mu \mathrm{L}, 1.0 \mathrm{mmol})$ was added to the reaction mixture using a microsyringe. After addition of the phosphine, the solution gradually changed color to light yellow. The reaction was stirred at room temperature and monitored through TLC $\left[\mathbf{1 b}: R_{\mathrm{f}}(\mathrm{EtOAc})=0.0 ; R_{\mathrm{f}}\left(10 \% \mathrm{MeOH}\right.\right.$ in $\left.\left.\mathrm{CH}_{2} \mathrm{Cl}_{2}\right)=0.34\right]$. After $6 \mathrm{~h}$, the mixture was concentrated and subjected to FCC, first with EtOAc to elute 4-pyridinecarboxaldehyde and then with a gradient of $\mathrm{MeOH}(1-5 \%)$ in $\mathrm{CH}_{2} \mathrm{Cl}_{2}$ to elute the product. After concentration, $\mathbf{1 b}$ was isolated as a yellow solid (428.0 mg, 91\%). This reaction was repeated on a $15 \mathrm{mmol}$ scale with no appreciable variation in yield. 1b was further purified through crystallization from EtOAc/cyclohexane to produce translucent yellow crystals suitable for X-ray crystallography. Mp 98-101 ${ }^{\circ} \mathrm{C}$; IR (film) $v_{\max }$ 2958, 1630, 1504, 1482, $1233 \mathrm{~cm}^{-1} ;{ }^{1} \mathrm{H}$ NMR $\left(500 \mathrm{MHz}, \mathrm{CDCl}_{3}\right)$ $\delta 8.53(\mathrm{dd}, J=4.6,1.3 \mathrm{~Hz}, 2 \mathrm{H}), 7.47(\mathrm{dm}, J=7.5 \mathrm{~Hz}, 2 \mathrm{H}), 7.33-7.25(\mathrm{~m}, 3 \mathrm{H}), 7.23$ (dd, $J=4.5$, $1.4 \mathrm{~Hz}, 2 \mathrm{H}), 4.86\left(\mathrm{~d}, J_{\mathrm{HP}}=15.5 \mathrm{~Hz}, 1 \mathrm{H}\right), 3.29(\mathrm{~s}, 3 \mathrm{H}), 2.29-2.21(\mathrm{~m}, 3 \mathrm{H}), 2.18-2.09$ (m, 3H), $1.42-1.31(\mathrm{~m}, 9 \mathrm{H}), 1.30-1.27(\mathrm{~m}, 3 \mathrm{H}), 7.11(\mathrm{t}, J=7.1 \mathrm{~Hz}, 9 \mathrm{H}) ;{ }^{13} \mathrm{C}$ NMR $\left(125 \mathrm{MHz}, \mathrm{CDCl}_{3}\right) \delta$ $181.9,169.1\left(\mathrm{~d}, J_{\mathrm{CP}}=9.9 \mathrm{~Hz}\right), 153.8,148.5(2 \mathrm{C}), 136.8\left(\mathrm{~d}, J_{\mathrm{CP}}=2.0 \mathrm{~Hz}\right), 129.4\left(\mathrm{~d}, J_{\mathrm{CP}}=4.9 \mathrm{~Hz}\right.$, 2C), $128.7\left(\mathrm{~d}, J_{\mathrm{CP}}=2.1 \mathrm{~Hz}, 2 \mathrm{C}\right), 127.7\left(\mathrm{~d}, J_{\mathrm{CP}}=3.1 \mathrm{~Hz}\right), 121.4(2 \mathrm{C}), 93.9\left(\mathrm{~d}, J_{\mathrm{CP}}=2.1 \mathrm{~Hz}\right), 49.7$, $40.6\left(\mathrm{~d}, J_{\mathrm{CP}}=50.1 \mathrm{~Hz}\right), 24.5\left(\mathrm{~d}, J_{\mathrm{CP}}=4.7 \mathrm{~Hz}, 3 \mathrm{C}\right), 24.0\left(\mathrm{~d}, J_{\mathrm{CP}}=15.0 \mathrm{~Hz}, 3 \mathrm{C}\right), 21.5\left(\mathrm{~d}, J_{\mathrm{CP}}=\right.$ $48.9 \mathrm{~Hz}, 3 \mathrm{C}), 13.1$ (3C); ${ }^{31} \mathrm{P} \mathrm{NMR}\left(202 \mathrm{MHz}, \mathrm{CDCl}_{3}\right) \delta$ 32.3; MS (MALDI) calcd for $\mathrm{C}_{28} \mathrm{H}_{41} \mathrm{NO}_{3} \mathrm{P}[\mathrm{M}+\mathrm{H}]^{+} 470.27$, found 470.36 .
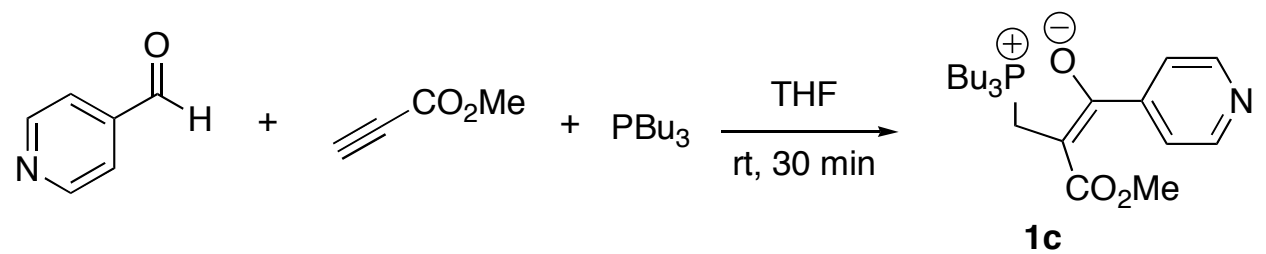

THF $(10 \mathrm{~mL}), 4$-pyridinecarboxaldehyde $(286 \mu \mathrm{L}, 3.0 \mathrm{mmol})$, methyl propiolate $(89 \mu \mathrm{L}, 1.0$ mmol), and tri- $n$-butylphosphine $(275 \mu \mathrm{L}, 1.1 \mathrm{mmol})$ were added by syringe sequentially to a flame-dried 25-mL round-bottom flask under argon. Immediately after addition of the phosphine, the solution changed color to dark red. The reaction was stirred at room temperature for $30 \mathrm{~min}$ and monitored by TLC $\left[1 \mathrm{c}: R_{\mathrm{f}}(\right.$ EtOAc $)=0.0 ; R_{\mathrm{f}}\left(10 \% \mathrm{MeOH}\right.$ in $\left.\left.\mathrm{CH}_{2} \mathrm{Cl}_{2}\right)=0.28\right]$. The mixture was concentrated and subjected to FCC, first with EtOAc to elute 4-pyridinecarboxaldehyde and then with a gradient of $\mathrm{MeOH}(1-10 \%)$ in $\mathrm{CH}_{2} \mathrm{Cl}_{2}$ to elute 1c, which was collected as a red oil 
(373.7 mg, 95\%). IR (neat) $v_{\max } 2959,1626,1500,1083 \mathrm{~cm}^{-1} ;{ }^{1} \mathrm{H}$ NMR $\left(500 \mathrm{MHz}, \mathrm{CDCl}_{3}\right) \delta$ $8.45(\mathrm{dd}, J=4.4,1.4 \mathrm{~Hz}, 2 \mathrm{H}), 7.12(\mathrm{dd}, J=4.5,1.4 \mathrm{~Hz}, 2 \mathrm{H}), 3.38\left(\mathrm{~d}, J_{\mathrm{CP}}=10.1 \mathrm{~Hz}, 2 \mathrm{H}\right), 3.30(\mathrm{~s}$, $3 \mathrm{H}), 2.06-1.99(\mathrm{~m}, 6 \mathrm{H}), 1.56-1.42(\mathrm{~m}, 12 \mathrm{H}), 0.92(\mathrm{t}, J=7.3 \mathrm{~Hz}, 9 \mathrm{H}) ;{ }^{13} \mathrm{C} \mathrm{NMR}(125 \mathrm{MHz}$, $\left.\mathrm{CDCl}_{3}\right) \delta 184.0,169.6,153.9,148.7(2 \mathrm{C}), 121.4(2 \mathrm{C}), 81.7\left(\mathrm{~d}, J_{\mathrm{CP}}=6.6 \mathrm{~Hz}\right), 49.5,24.0\left(\mathrm{~d}, J_{\mathrm{CP}}=\right.$ $14.1 \mathrm{~Hz}, 3 \mathrm{C}), 23.7$ (d, $\left.J_{\mathrm{CP}}=4.4 \mathrm{~Hz}, 3 \mathrm{C}\right), 20.0\left(\mathrm{~d}, J_{\mathrm{CP}}=48.4 \mathrm{~Hz}\right), 19.7$ (d, $\left.J_{\mathrm{CP}}=46.3 \mathrm{~Hz}, 3 \mathrm{C}\right)$, $13.4(3 \mathrm{C}) ;{ }^{31} \mathrm{P}$ NMR (202 MHz, $\left.\mathrm{CDCl}_{3}\right) \delta 32.4$; MS (MALDI) calcd for $\mathrm{C}_{22} \mathrm{H}_{37} \mathrm{NO}_{3} \mathrm{P}[\mathrm{M}+\mathrm{H}]^{+}$ 394.25, found 394.18 .

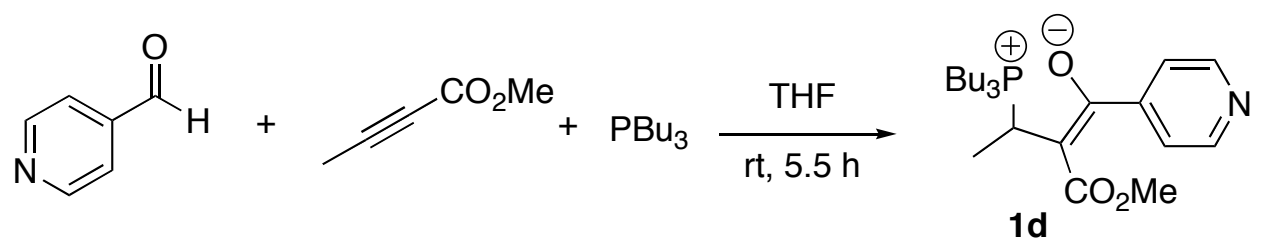

THF (10 mL), 4-pyridinecarboxaldehyde (286 $\mu \mathrm{L}, 1.0 \mathrm{mmol})$, methyl 2-butynoate (100 $\mu \mathrm{L}, 1.0$ mmol), and tri- $n$-butylphosphine $(275 \mu \mathrm{L}, 1.1 \mathrm{mmol})$ were added sequentially to a flame-dried 25-mL round-bottom flask under argon. Immediately after addition of the phosphine, the solution changed color to dark red. The reaction was stirred at room temperature for $5.5 \mathrm{~h}$ and monitored by TLC $\left[\mathbf{1 d}: R_{\mathrm{f}}(\right.$ EtOAc $)=0.0 ; R_{\mathrm{f}}\left(10 \% \mathrm{MeOH}\right.$ in $\left.\left.\mathrm{CH}_{2} \mathrm{Cl}_{2}\right)=0.34\right]$. The mixture was concentrated and subjected to FCC, first with EtOAc to elute 4-pyridinecarboxaldehyde and several byproducts. The major product of this reaction was 1,3-dioxan-4-ylidene (isolated yield: $50 \%$ ). The phosphine-catalyzed synthesis of 1,3-dioxane-4-ylidenes was reported from our lab. ${ }^{1}$ Upon treatment with phosphine, 2-butynoate forms $\beta$-phosphonium dienolate zwitterion that is a reactive intermediate in the phosphine-catalyzed synthesis of 1,3-dioxane-4-ylidenes. ${ }^{2}$ Next, a gradient of $\mathrm{MeOH}(1-10 \%)$ in $\mathrm{CH}_{2} \mathrm{Cl}_{2}$ was used to elute 1d as a red oil (134 mg, 33\%). IR (film) $v_{\max } 2959,1731,1629,1503,1482 \mathrm{~cm}^{-1} ;{ }^{1} \mathrm{H}$ NMR $\left(500 \mathrm{MHz}, \mathrm{CDCl}_{3}\right) \delta 8.49(\mathrm{dd}, J=5.8,0.97$ $\mathrm{Hz}, 2 \mathrm{H}), 7.13(\mathrm{dd}, J=6.3,0.5 \mathrm{~Hz}, 2 \mathrm{H}), 4.02-3.97(\mathrm{~m}, 1 \mathrm{H}), 3.30$ (s, 3H), 2.24-2.18 (m, 3H), 2.09-2.04 (m, 3H), 1.59-1.43 (m, 15H), $0.96(\mathrm{t}, J=7.0 \mathrm{~Hz}, 9 \mathrm{H}) ;{ }^{13} \mathrm{C} \mathrm{NMR}\left(125 \mathrm{MHz}, \mathrm{CDCl}_{3}\right) \delta$ 182.7, $169.5\left(\mathrm{~d}, J_{\mathrm{CP}}=5.9 \mathrm{~Hz}\right), 154.3,148.6(2 \mathrm{C}), 121.5(2 \mathrm{C}), 91.8,49.6,28.0\left(\mathrm{~d}, J_{\mathrm{CP}}=37.8 \mathrm{~Hz}\right)$, $24.4\left(\mathrm{~d}, J_{\mathrm{CP}}=4.9 \mathrm{~Hz}, 3 \mathrm{C}\right), 24.3\left(\mathrm{~d}, J_{\mathrm{CP}}=14.4 \mathrm{~Hz}, 3 \mathrm{C}\right), 20.2(\mathrm{~d}, J=46.6 \mathrm{~Hz}, 3 \mathrm{C}), 14.3,13.5$ (3C); ${ }^{31} \mathrm{P} \mathrm{NMR}\left(202 \mathrm{MHz}, \mathrm{CDCl}_{3}\right) \delta$ 35.8; MS (MALDI) calcd for $\mathrm{C}_{23} \mathrm{H}_{39} \mathrm{NO}_{3} \mathrm{P}[\mathrm{M}+\mathrm{H}]^{+}$ 408.27, found 408.28.

\footnotetext{
${ }^{1}$ Zhu, X.-F.; Henry, C. E.; Wang, J.; Dudding, T.; Kwon, O. Org. Lett. 2005, 7, 1387.

${ }^{2}$ Lu, X.; Zhang, C.; Zu, Z. Acc. Chem. Res. 2001, 34, 535.
} 


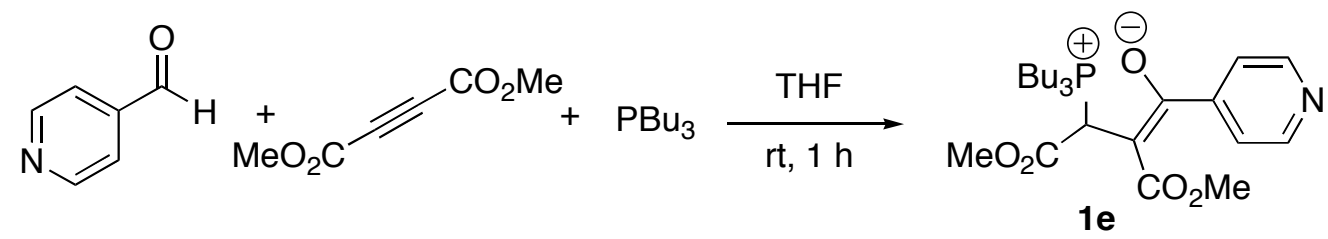

THF (10 mL), 4-pyridinecarboxaldehyde (573 $\mu \mathrm{L}, 6.0 \mathrm{mmol})$, dimethyl acetylenedicarboxylate (610 mg, $2.0 \mathrm{mmol})$, and tri- $n$-butylphosphine $(500 \mu \mathrm{L}, 2.0 \mathrm{mmol})$ were added sequentially to a flame-dried $25-\mathrm{mL}$ round-bottom flask under argon. Immediately after addition of the phosphine, the solution changed color to dark red. The reaction was stirred at room temperature for $1 \mathrm{~h}$ and monitored by TLC [1e: $R_{\mathrm{f}}(\mathrm{EtOAc})=0.0 ; R_{\mathrm{f}}\left(10 \% \mathrm{MeOH}\right.$ in $\left.\left.\mathrm{CH}_{2} \mathrm{Cl}_{2}\right)=0.34\right]$. The mixture was concentrated and subjected to FCC, first with EtOAc to elute 4-pyridinecarboxaldehyde and then with a gradient of $\mathrm{MeOH}(1-10 \%)$ in $\mathrm{CH}_{2} \mathrm{Cl}_{2}$ to elute 1e as a red oil $(761.1 \mathrm{mg}, 84 \%)$. 1e was further purified through crystallization: 1e was dissolved in a minimal amount of hot toluene, pentanes were added until the solution was slightly cloudy, and then the solution was placed in a freezer at $-20{ }^{\circ} \mathrm{C}$ for 3 days; a white solid was observed as a heterogeneous precipitate in addition to some red oil. The solid was recrystallized from toluene/EtOAc. IR (film) $v_{\max } 2924$, 1740, 1465, $1182 \mathrm{~cm}^{-1} ;{ }^{1} \mathrm{H}$ NMR (500 MHz, $\left.\mathrm{CDCl}_{3}\right) \delta 8.52(\mathrm{dd}, J=4.4,1.4 \mathrm{~Hz}, 2 \mathrm{H}), 7.19(\mathrm{dd}, J$ $=4.6,1.2 \mathrm{~Hz}, 2 \mathrm{H}), 5.45\left(\mathrm{~d}, J_{\mathrm{HP}}=16.0 \mathrm{~Hz}, 1 \mathrm{H}\right), 3.71(\mathrm{~s}, 3 \mathrm{H}), 3.33(\mathrm{~s}, 3 \mathrm{H}), 2.28-2.23(\mathrm{~m}, 3 \mathrm{H})$, $2.21-2.12(\mathrm{~m}, 3 \mathrm{H}), 1.65-1.41(\mathrm{~m}, 12 \mathrm{H}), 0.92(\mathrm{t}, J=7.2 \mathrm{~Hz}, 9 \mathrm{H}) ;{ }^{13} \mathrm{C}$ NMR $\left(125 \mathrm{MHz}, \mathrm{CDCl}_{3}\right) \delta$ 184.1, 171.4, 169.1, 153.1, 148.8 (2C), 121.5 (2C), 85.1, 52.8, 49.7, 40.7 (d, $\left.J_{\mathrm{CP}}=60.7 \mathrm{~Hz}\right), 24.3$ $\left(\mathrm{d}, J_{\mathrm{CP}}=4.6 \mathrm{~Hz}, 3 \mathrm{C}\right), 24.2\left(\mathrm{~d}, J_{\mathrm{CP}}=15.2 \mathrm{~Hz}, 3 \mathrm{C}\right), 19.9\left(\mathrm{~d}, J_{\mathrm{CP}}=45.9 \mathrm{~Hz}, 3 \mathrm{C}\right), 13.4(3 \mathrm{C}) ;{ }^{31} \mathrm{P}$ $\operatorname{NMR}\left(202 \mathrm{MHz}, \mathrm{CDCl}_{3}\right) \delta$ 36.2; MS (MALDI) calcd for $\mathrm{C}_{24} \mathrm{H}_{39} \mathrm{NO}_{5} \mathrm{P}[\mathrm{M}+\mathrm{H}]^{+} 452.26$, found 452.24 .

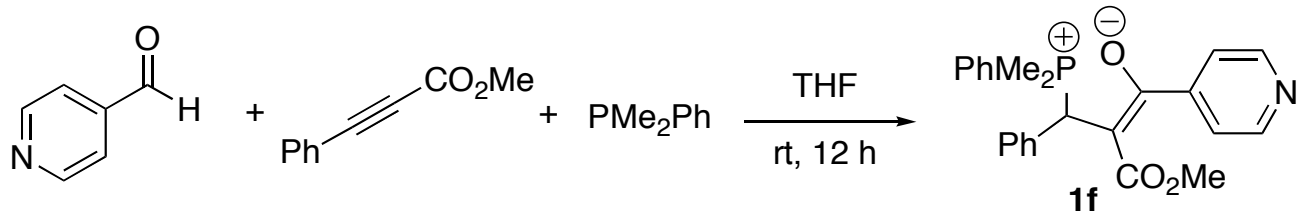

THF (10 mL), 4-pyridinecarboxaldehyde ( $286 \mu \mathrm{L}, 3.0 \mathrm{mmol})$, methyl propiolate $(89 \mu \mathrm{L}, 1.0$ $\mathrm{mmol})$, and dimethylphenylphosphine ( $142 \mu \mathrm{L}, 1.0 \mathrm{mmol})$ were added by syringe sequentially to a flame-dried $25-\mathrm{mL}$ round-bottom flask under argon. Immediately after addition of the phosphine, the solution changed color to dark red. The reaction was stirred at room temperature for $12 \mathrm{~h}$ and monitored by TLC. The mixture was concentrated and subjected to FCC, first with EtOAc to elute 4-pyridinecarboxaldehyde and then with a gradient of $\mathrm{MeOH}(1-10 \%)$ in $\mathrm{CH}_{2} \mathrm{Cl}_{2}$ 
to elute 1f, which was collected as a red oil (328 mg, 81\%). The product was recrystalized in 1:1 EtOAc:cyclohexane to yield crystals suitable for X-ray crystallography. Upon heating, $\mathbf{1 f}$ began to turn brown at $130{ }^{\circ} \mathrm{C}$ and rapidly decomposed at $144{ }^{\circ} \mathrm{C}$. IR (neat) $v_{\max } 2919,1634,1600$, 1505, $1237 \mathrm{~cm}^{-1} ;{ }^{1} \mathrm{H}$ NMR $\left(500 \mathrm{MHz}, \mathrm{CDCl}_{3}\right) \delta 8.44(\mathrm{dd}, J=4.4,1.5 \mathrm{~Hz}, 2 \mathrm{H}), 7.63-7.58(\mathrm{~m}$, 3H), 7.54-7.50 (m, 2H), 7.32-7.29 (m, 5H), $6.90(\mathrm{dd}, J=4.4,1.5 \mathrm{~Hz}, 2 \mathrm{H}), 4.96\left(\mathrm{~d}, J_{\mathrm{HP}}=13.4\right.$ $\mathrm{Hz}, 1 \mathrm{H}), 3.31(\mathrm{~s}, 3 \mathrm{H}), 2.15\left(\mathrm{~d}, J_{\mathrm{HP}}=8.50 \mathrm{~Hz}, 3 \mathrm{H}\right) 1.87\left(\mathrm{~d}, J_{\mathrm{HP}}=11.7 \mathrm{~Hz}, 3 \mathrm{H}\right) ;{ }^{13} \mathrm{C} \mathrm{NMR}(125$ $\left.\mathrm{MHz}, \mathrm{CDCl}_{3}\right) \delta 179.8\left(\mathrm{~d}, J_{\mathrm{CP}}=3.9 \mathrm{~Hz}\right), 168.5\left(\mathrm{~d}, J_{\mathrm{CP}}=11.5 \mathrm{~Hz}\right), 151.9,148.6(2 \mathrm{C}), 135.5(\mathrm{~d}$, $\left.J_{\mathrm{CP}}=3.5 \mathrm{~Hz}\right), 132.0(\mathrm{~d}, J=2.9 \mathrm{~Hz}), 129.7\left(\mathrm{~d}, J_{\mathrm{CP}}=8.1 \mathrm{~Hz}, 2 \mathrm{C}\right), 129.4\left(\mathrm{~d}, J_{\mathrm{CP}}=5.5 \mathrm{~Hz}, 2 \mathrm{C}\right)$, $128.7\left(\mathrm{~d}, J_{\mathrm{CP}}=11.6 \mathrm{~Hz}, 2 \mathrm{C}\right), 128.68(2 \mathrm{C}), 127.9\left(\mathrm{~d}, J_{\mathrm{CP}}=3.6 \mathrm{~Hz}\right), 127.6\left(\mathrm{~d}, J_{\mathrm{CP}}=85.2 \mathrm{~Hz}\right)$, $121.3(2 \mathrm{C}), 94.0,49.8,46.0\left(\mathrm{~d}, J_{\mathrm{CP}}=57.8 \mathrm{~Hz}\right), 13.5\left(\mathrm{~d}, J_{\mathrm{CP}}=56.0\right), 11.3\left(\mathrm{~d}, J_{\mathrm{CP}}=69.2 \mathrm{~Hz}\right) ;{ }^{31} \mathrm{P}$ NMR (202 MHz, $\left.\mathrm{CDCl}_{3}\right) \delta$ 17.4; MS (MALDI) calcd for $\mathrm{C}_{24} \mathrm{H}_{25} \mathrm{NO}_{3} \mathrm{P}[\mathrm{M}+\mathrm{H}]^{+}$406.16, found 406.15 .

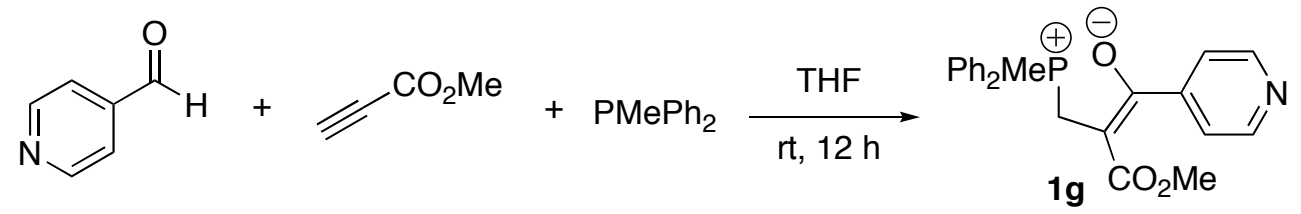

THF (10 mL), 4-pyridinecarboxaldehyde (286 $\mu \mathrm{L}, 3.0 \mathrm{mmol})$, methyl propiolate $(89 \mu \mathrm{L}, 1.0$ mmol), and methyldiphenylphosphine $(207 \mu \mathrm{L}, 1.0 \mathrm{mmol})$ were added by syringe sequentially to a flame-dried $25-\mathrm{mL}$ round-bottom flask under argon. Immediately after addition of the phosphine, the solution changed color to dark red. The reaction was stirred at room temperature for $12 \mathrm{~h}$ and monitored by TLC $\left[\mathbf{1 g}: R_{\mathrm{f}}(\mathrm{EtOAc})=0.0 ; R_{\mathrm{f}}\left(10 \% \mathrm{MeOH}\right.\right.$ in $\left.\left.\mathrm{CH}_{2} \mathrm{Cl}_{2}\right)=0.17\right]$. The mixture was concentrated and subjected to FCC, first with EtOAc to elute 4pyridinecarboxaldehyde and then with a gradient of $\mathrm{MeOH}(1-10 \%)$ in $\mathrm{CH}_{2} \mathrm{Cl}_{2}$ to elute $\mathbf{1 g}$, which was collected as a red oil (301.4 mg, 77\%). IR (neat) $v_{\max }$ 3060, 1729, 1662, 1498, 1479 $\mathrm{cm}^{-1} ;{ }^{1} \mathrm{H}$ NMR $\left(500 \mathrm{MHz}, \mathrm{CDCl}_{3}\right) \delta 8.44(\mathrm{dd}, J=4.4,1.5 \mathrm{~Hz}, 2 \mathrm{H}), 7.63-7.58(\mathrm{~m}, 3 \mathrm{H}), 7.54-$ $7.50(\mathrm{~m}, 2 \mathrm{H}), 7.32-7.29(\mathrm{~m}, 5 \mathrm{H}), 6.90(\mathrm{dd}, J=4.4,1.5 \mathrm{~Hz}, 2 \mathrm{H}), 4.96\left(\mathrm{~d}, J_{\mathrm{HP}}=13.4 \mathrm{~Hz}, 1 \mathrm{H}\right)$, $3.31(\mathrm{~s}, 3 \mathrm{H}), 2.15\left(\mathrm{~d}, J_{\mathrm{HP}}=8.50 \mathrm{~Hz}, 3 \mathrm{H}\right) 1.87\left(\mathrm{~d}, J_{\mathrm{HP}}=11.7 \mathrm{~Hz}, 3 \mathrm{H}\right) ;{ }^{13} \mathrm{C} \mathrm{NMR}(125 \mathrm{MHz}$, $\left.\mathrm{CDCl}_{3}\right) \delta 183.5,169.2,153.4,148.6(2 \mathrm{C}), 133.6\left(\mathrm{~d}, J_{\mathrm{CP}}=2.5 \mathrm{~Hz}, 2 \mathrm{C}\right), 132.0\left(\mathrm{~d}, J_{\mathrm{CP}}=9.3 \mathrm{~Hz}\right.$, 4C), $129.4(\mathrm{~d}, J=11.9 \mathrm{~Hz}, 4 \mathrm{C}), 122.7\left(\mathrm{~d}, J_{\mathrm{CP}}=79.6 \mathrm{~Hz}, 2 \mathrm{C}\right), 121.4(2 \mathrm{C}), 82.8,49.4,25.7\left(\mathrm{~d}, J_{\mathrm{CP}}\right.$ $=47.8 \mathrm{~Hz}), 9.6\left(\mathrm{~d}, J_{\mathrm{CP}}=58.5 \mathrm{~Hz}\right) ;{ }^{31} \mathrm{P} \mathrm{NMR}\left(202 \mathrm{MHz}, \mathrm{CDCl}_{3}\right) \delta$ 22.4; MS (MALDI) calcd for $\mathrm{C}_{23} \mathrm{H}_{23} \mathrm{NO}_{3} \mathrm{P}[\mathrm{M}+\mathrm{H}]^{+}$392.14, found 392.17. 


\section{Formation of a Trace Amount of Dioxane S1 and Its Mechanistic Implications}

A second product was observed in several of the reactions. This compound was assigned the structure $\mathbf{S 1}$ based on ${ }^{1} \mathrm{H}$ NMR spectroscopic data. ${ }^{1} \mathrm{H}$ NMR $\left(500 \mathrm{MHz}, \mathrm{CDCl}_{3}\right) \delta 8.68(\mathrm{dd}, J=$ 4.5, 1.5 Hz, 2H), $8.62(\mathrm{~d}, J=6.0 \mathrm{~Hz}, 2 \mathrm{H}), 7.93(\mathrm{~s}, 1 \mathrm{H}), 7.50-7.43(\mathrm{~m}, 4 \mathrm{H}), 5.99(\mathrm{~s}, 1 \mathrm{H}), 5.816(\mathrm{~s}$, $1 \mathrm{H})$.

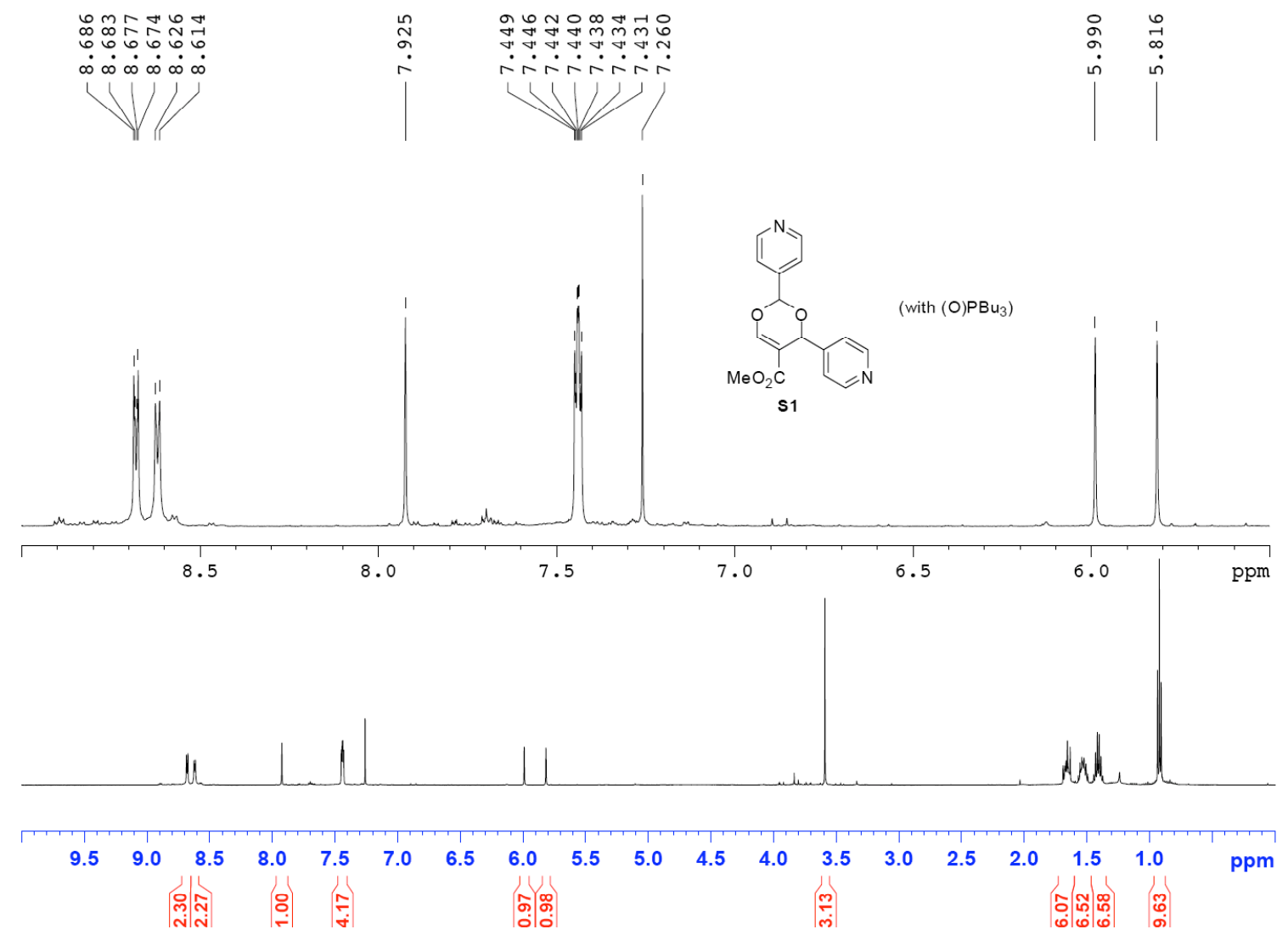

Our proposed mechanism begins with conjugate addition of the phosphine to the propiolate, forming the vinyl anion 2 (Scheme S1). The anion 2 then adds to 4-pyridinecarboxaldehyde to form the zwitterion 3. At this point, a branching point in the mechanism is reached. Consecutive proton transfer processes afford $\mathbf{1}$ (as is discussed in the text), while addition of $\mathbf{3}$ to another molecule of 4-pyridinecarboxaldehyde provides zwitterion S2, which can undergo 6-endo cyclization, followed by elimination, to provide $\mathbf{S 1}$ via the intermediate $\mathbf{S 3}$. 
Scheme S1. Proposed mechanism for the formation of $\mathbf{1}$ and S1

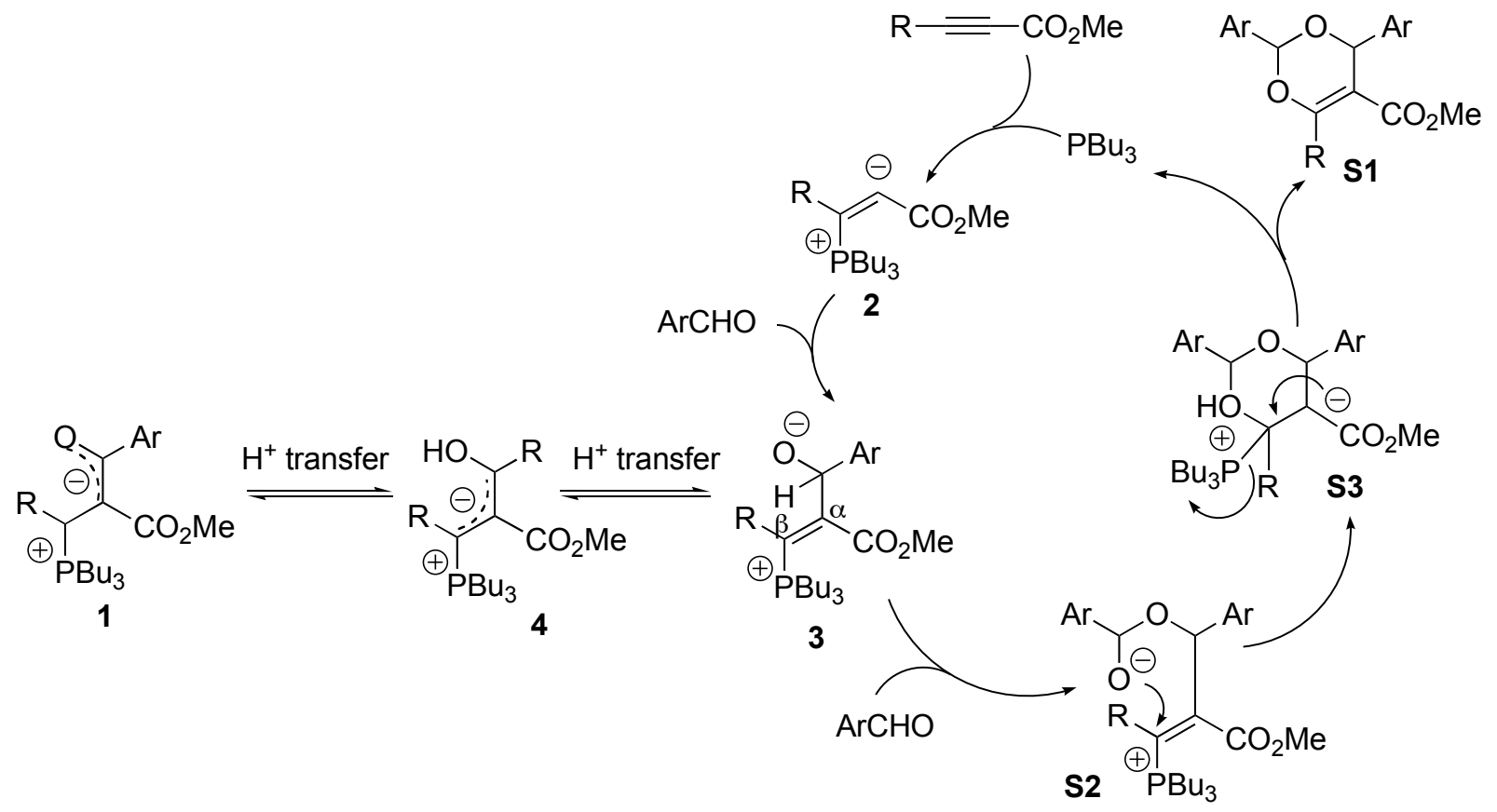

The results of reactions using various substituted methyl propiolates are summarized in Table $\mathrm{S} 1$. The yield of $\mathbf{S 1}$ was highest when electron-rich propiolates were used in the reaction (Table S1, entries 1 and 2) and lowest (or negligible) when using electron-deficient propiolates (Table S1, entries 3 and 4). This observation is in accordance with the mechanism proposed above. An electron-withdrawing substituent at the $\beta$ carbon atom stabilizes intermediate 4 and, therefore, facilitates the proton transfer process to form 4; it does, however, diminish the nucleophilicity of the alkoxide toward addition to another aldehyde, which abates the formation of $\mathbf{S 2}$.

Table S1. Formation of zwitterion 1 and dioxane S1

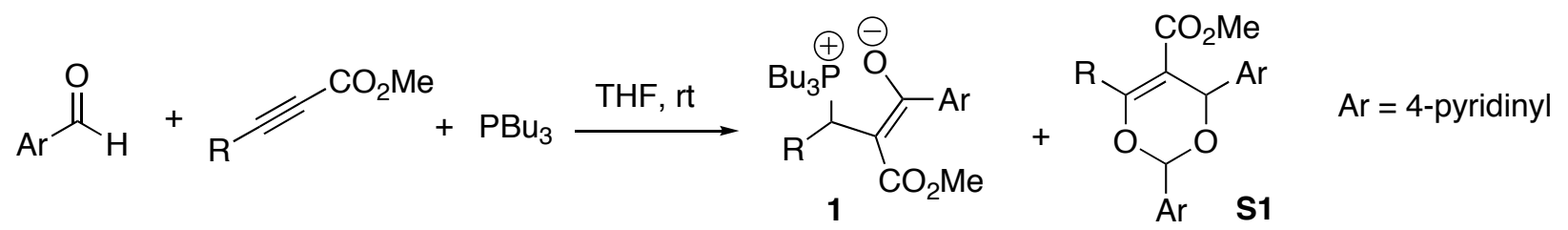

\begin{tabular}{llll}
\hline Entry & $\mathrm{R}$ & Isolated yield of $\mathbf{1}(\%)$ & Isolated yield of S1 (\%) \\
\hline 1 & $\mathrm{Me}$ & 33 & 7 \\
2 & $\mathrm{H}$ & 95 & 5 \\
3 & $\mathrm{Ph}$ & 91 & 0.5 \\
4 & $\mathrm{CO}_{2} \mathrm{Me}$ & 83 & 0 \\
\hline
\end{tabular}


${ }^{1} \mathrm{H},{ }^{13} \mathrm{C}$, and ${ }^{31} \mathrm{P}$ NMR Spectra of New Compounds.
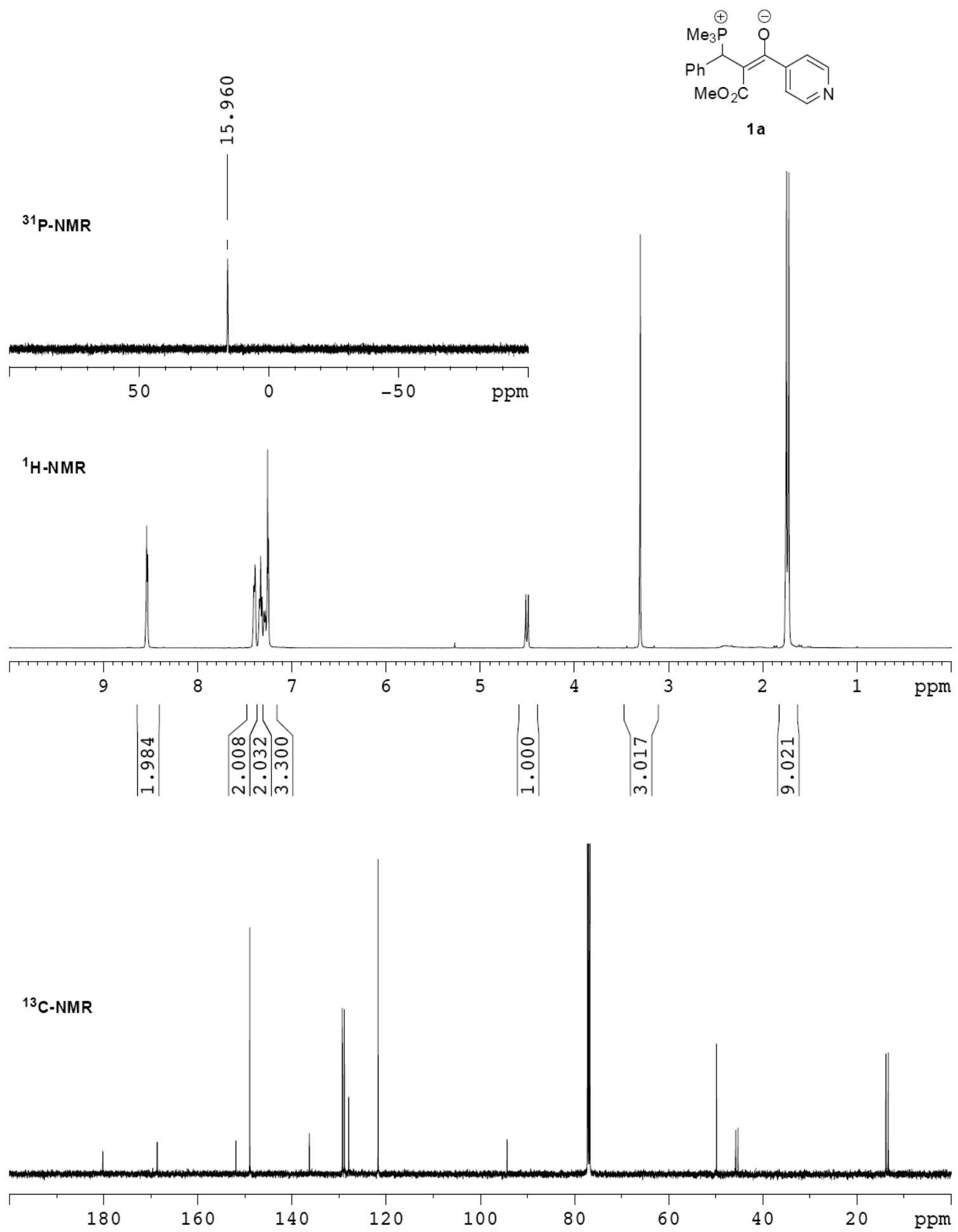

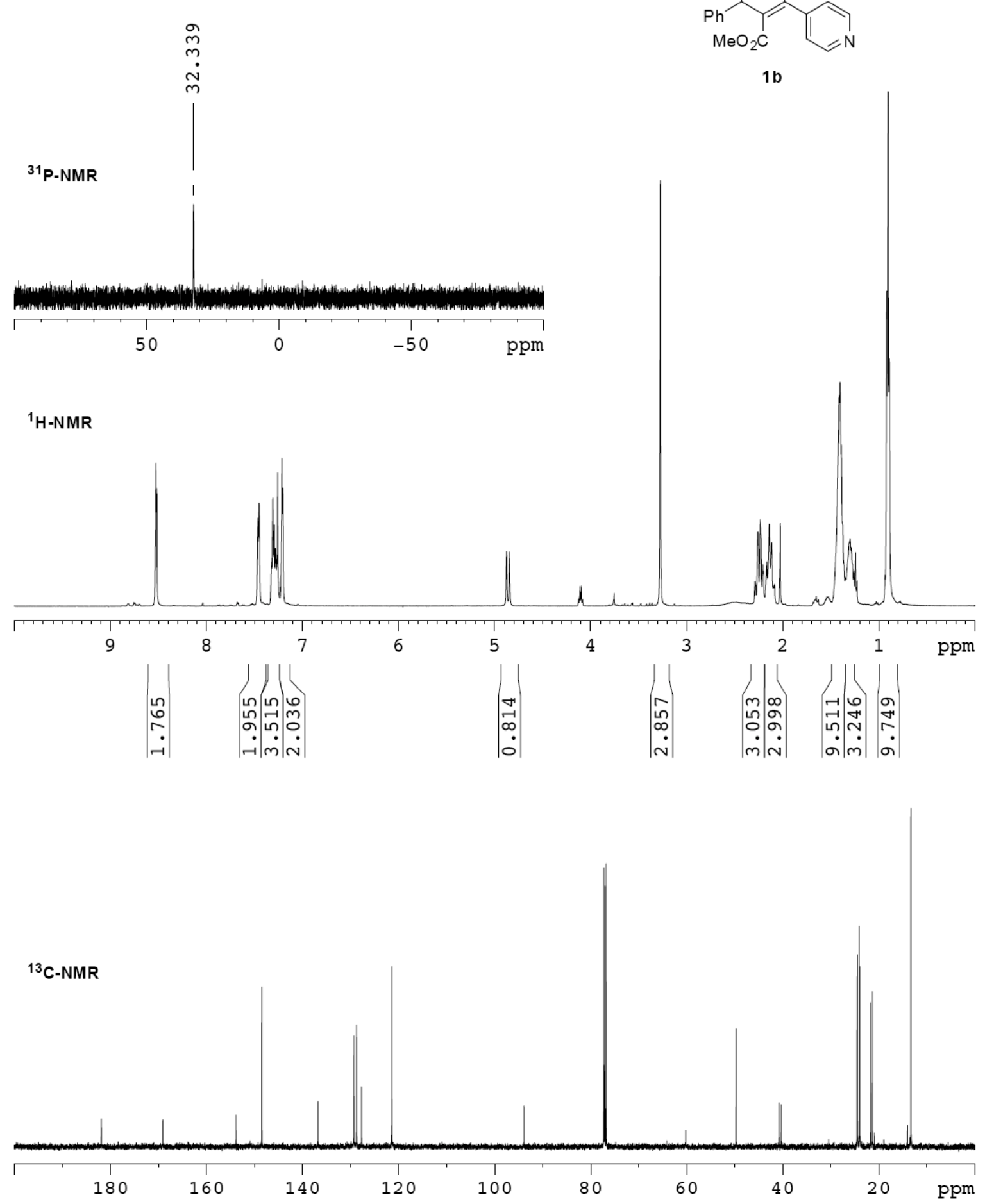

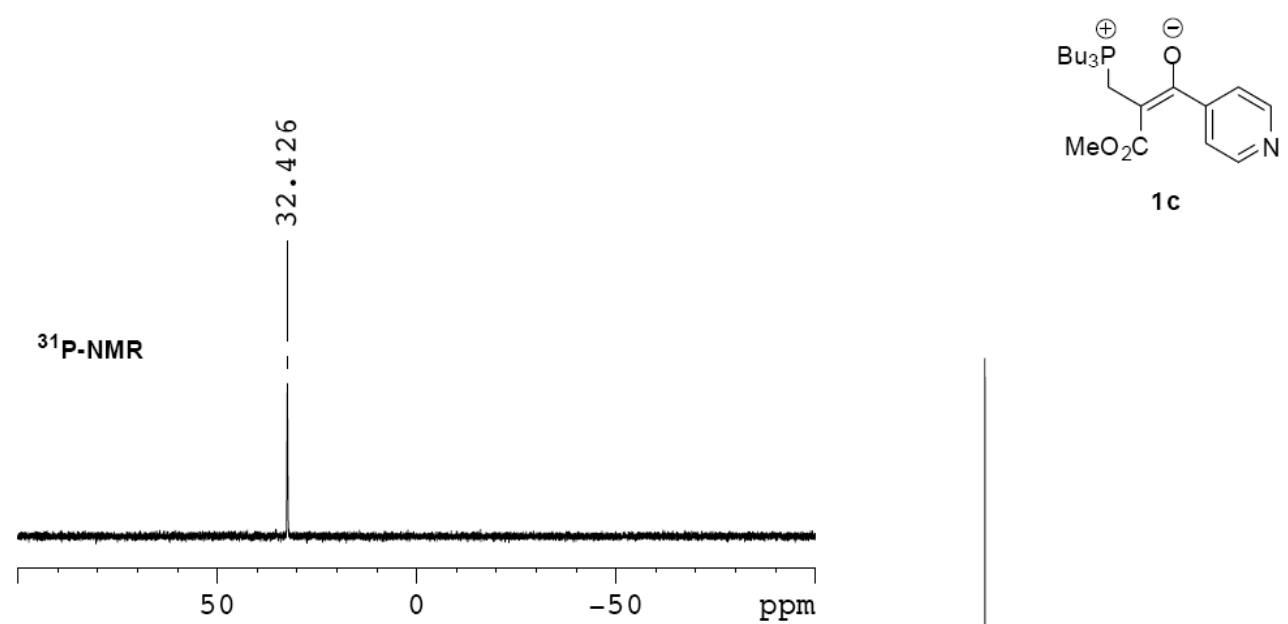

$1 c$
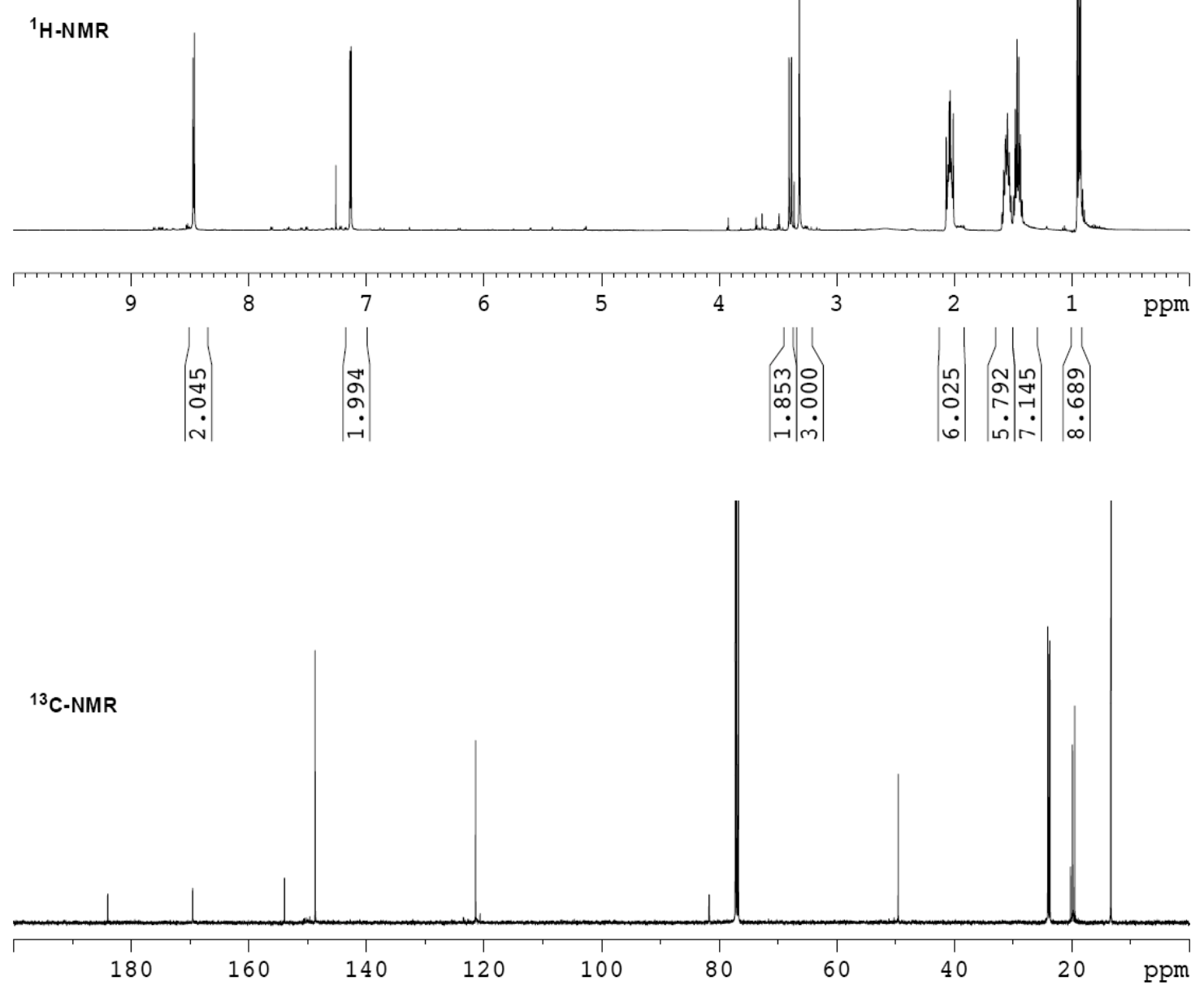

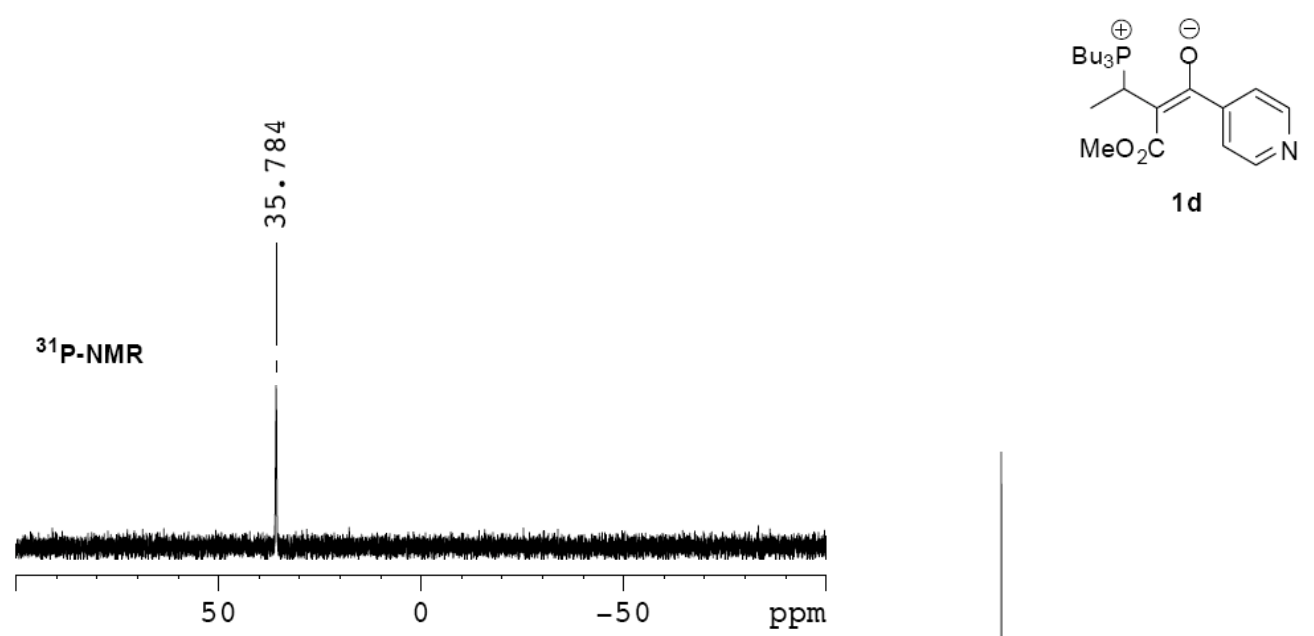

${ }^{1}$ H-NMR
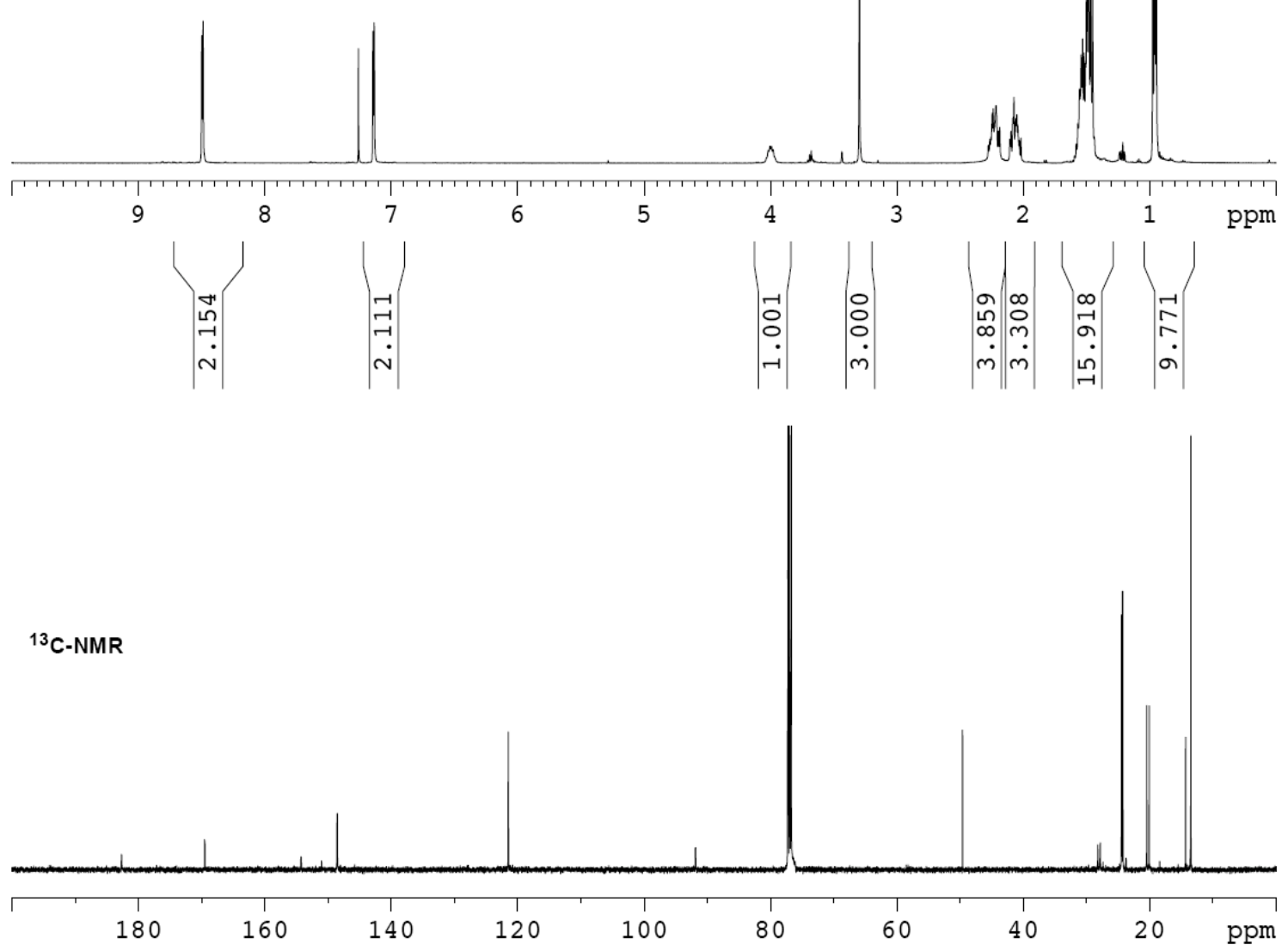

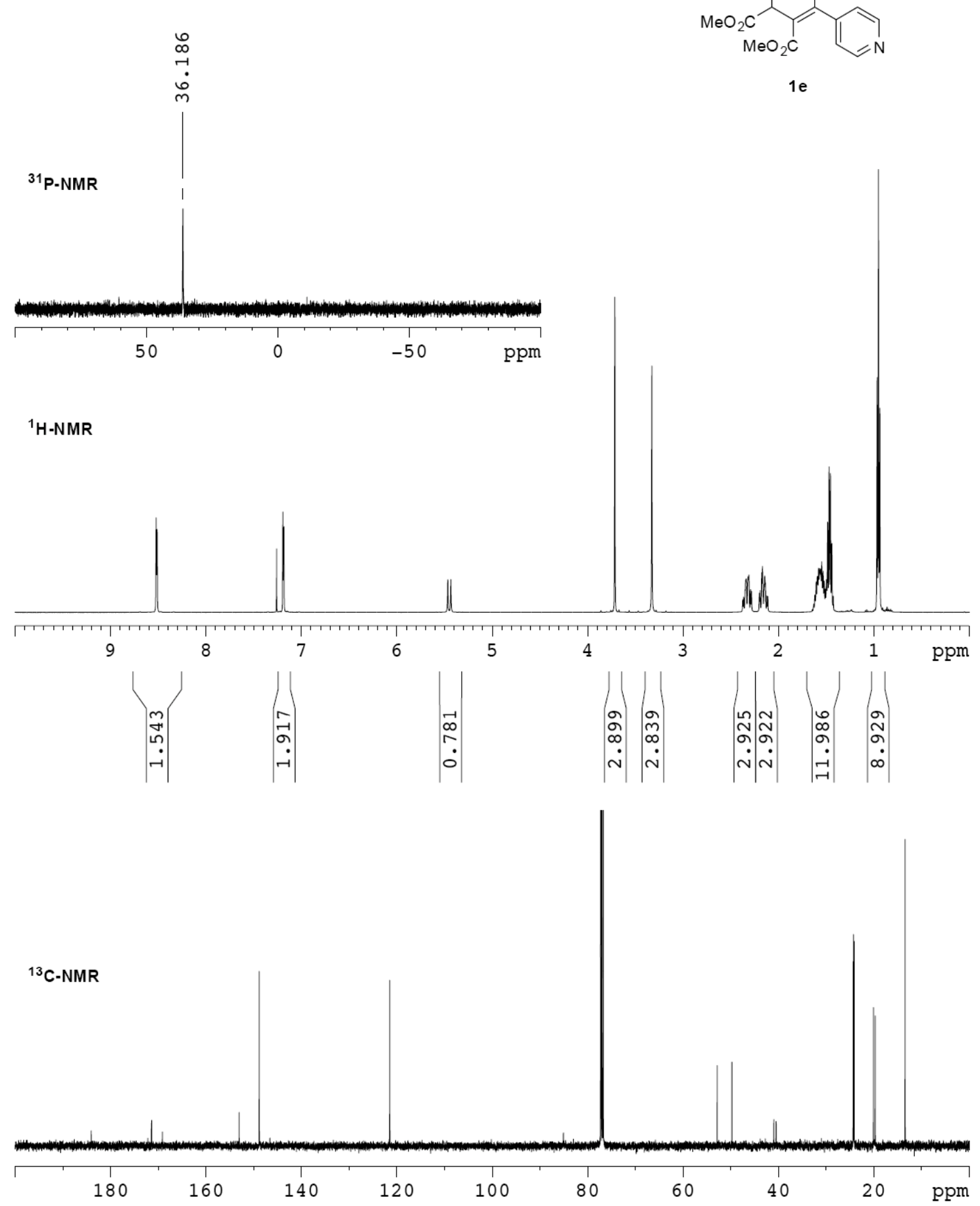

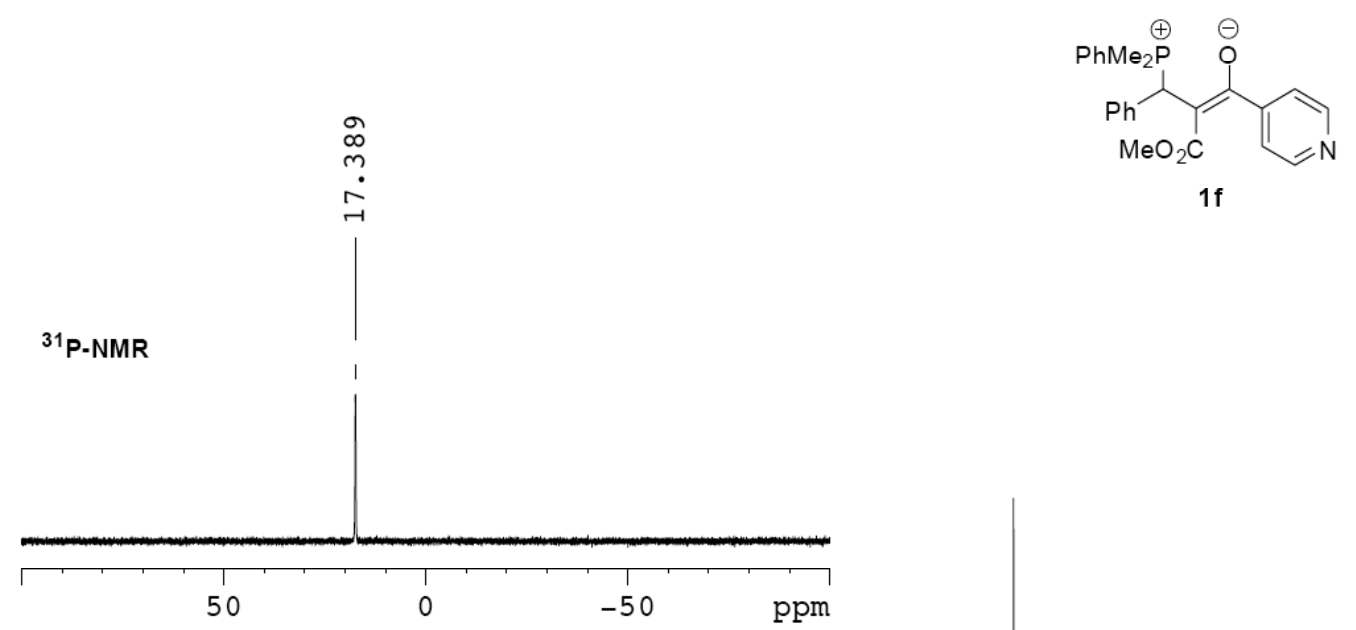

${ }^{1}$ H-NMR
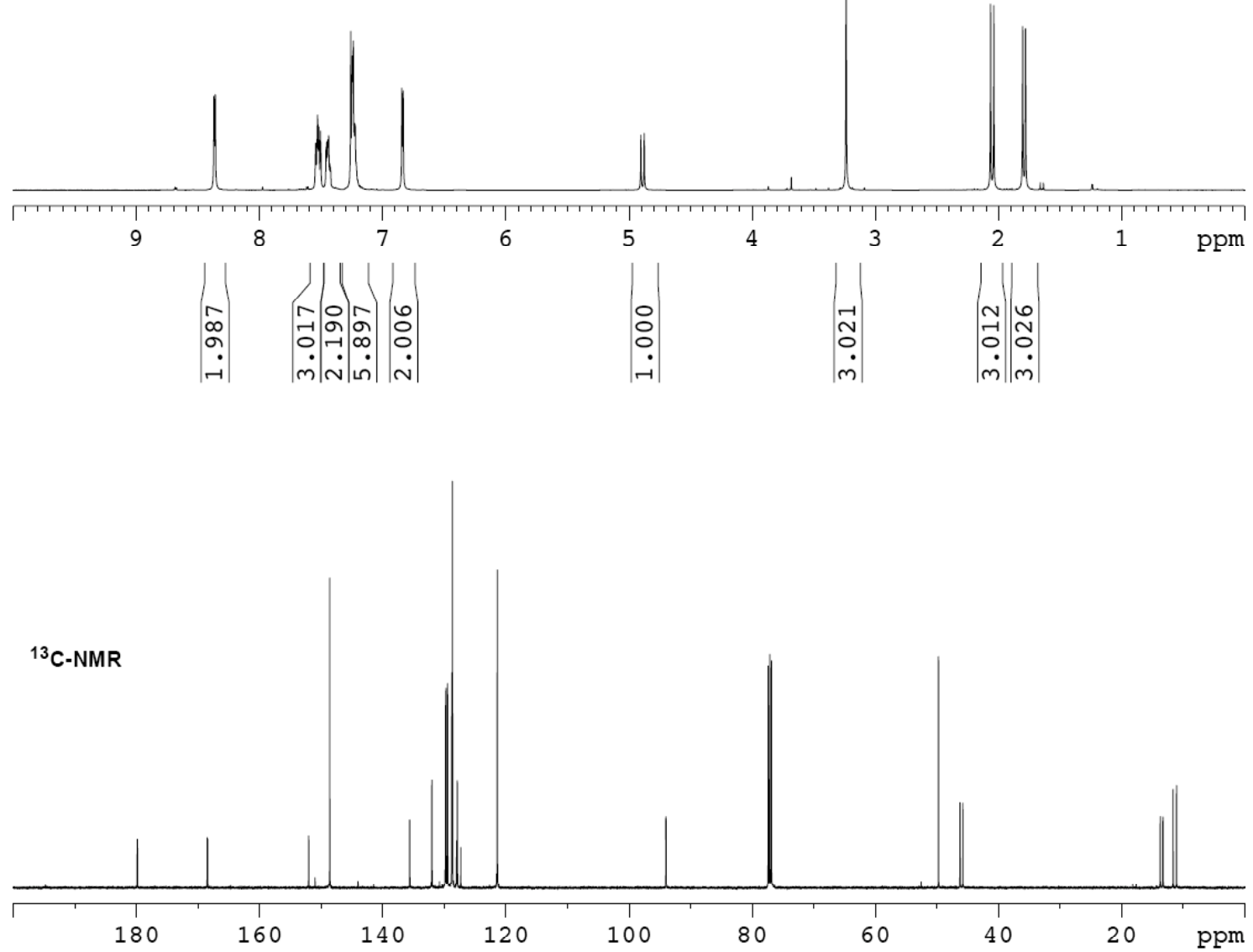

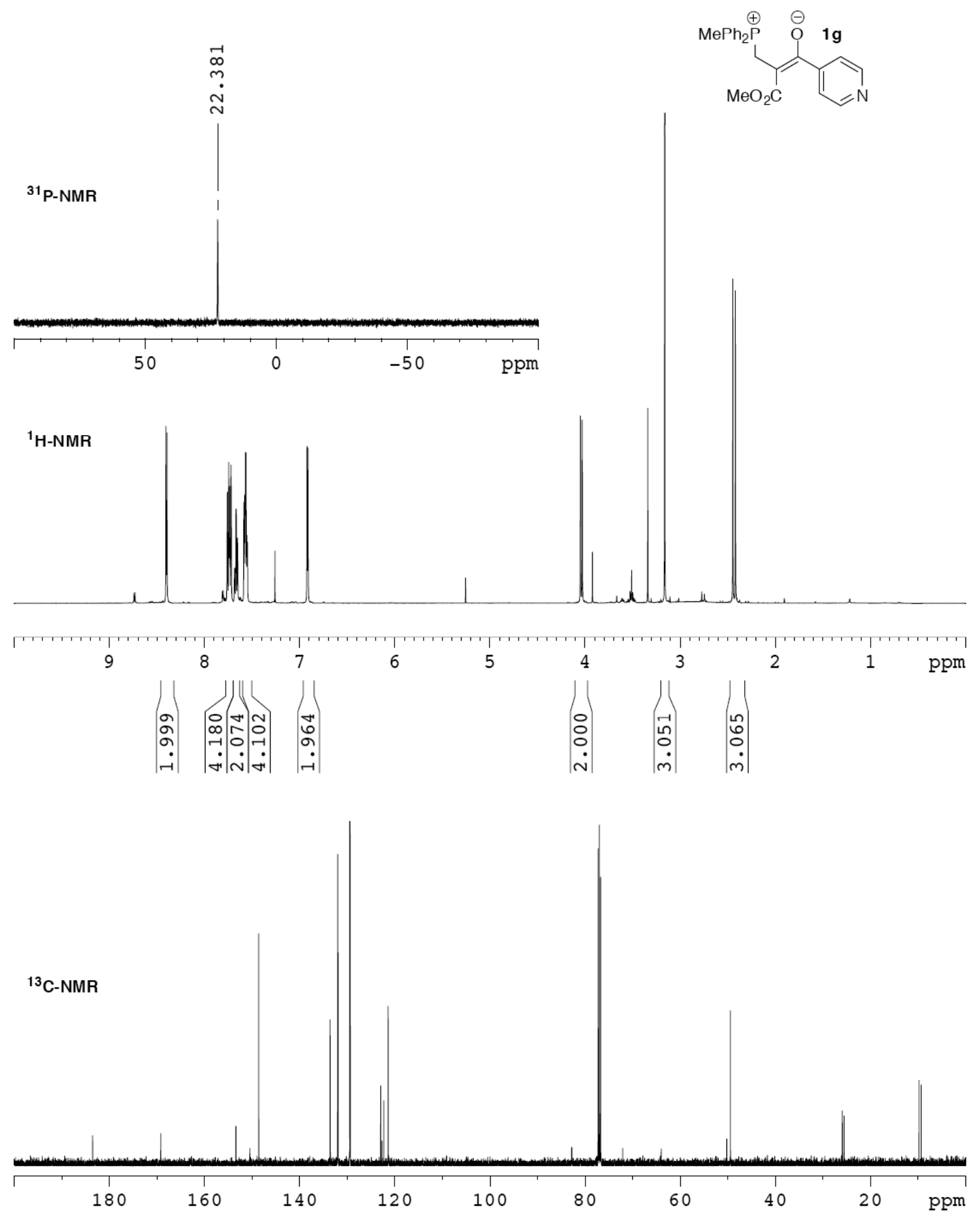


\section{ORTEP Representations of Zwitterions 1}

Crystallographic data for 1a, $\mathbf{1 b}$ and $\mathbf{1 f}$ have been deposited with the Cambridge

Crystallographic Data Centre as supplementary numbers CCDC 638772-638774. These data can be obtained online free of charge (or from the Cambridge Crystallographic Data Center, 12, Union Road, Cambridge CB2 1EZ, UK; fax: (+44) 1223-336-033; or deposit@ccdc.cam.ac.uk).

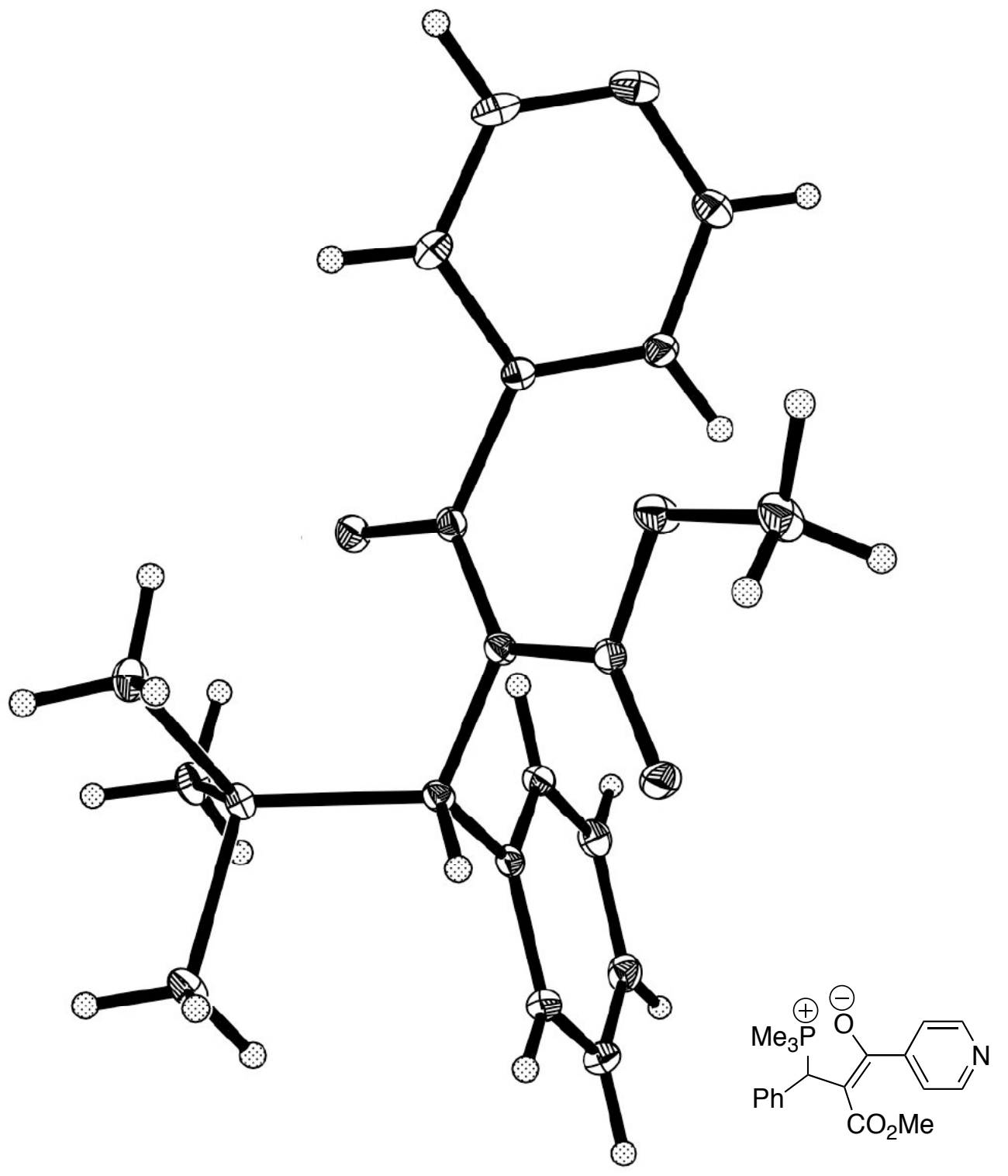


The short interatomic distances in the X-ray structure of compound $\mathbf{1 b}$ are due to the second orientation of one of the flexible $n$-butyl groups on the phosphorous atom.

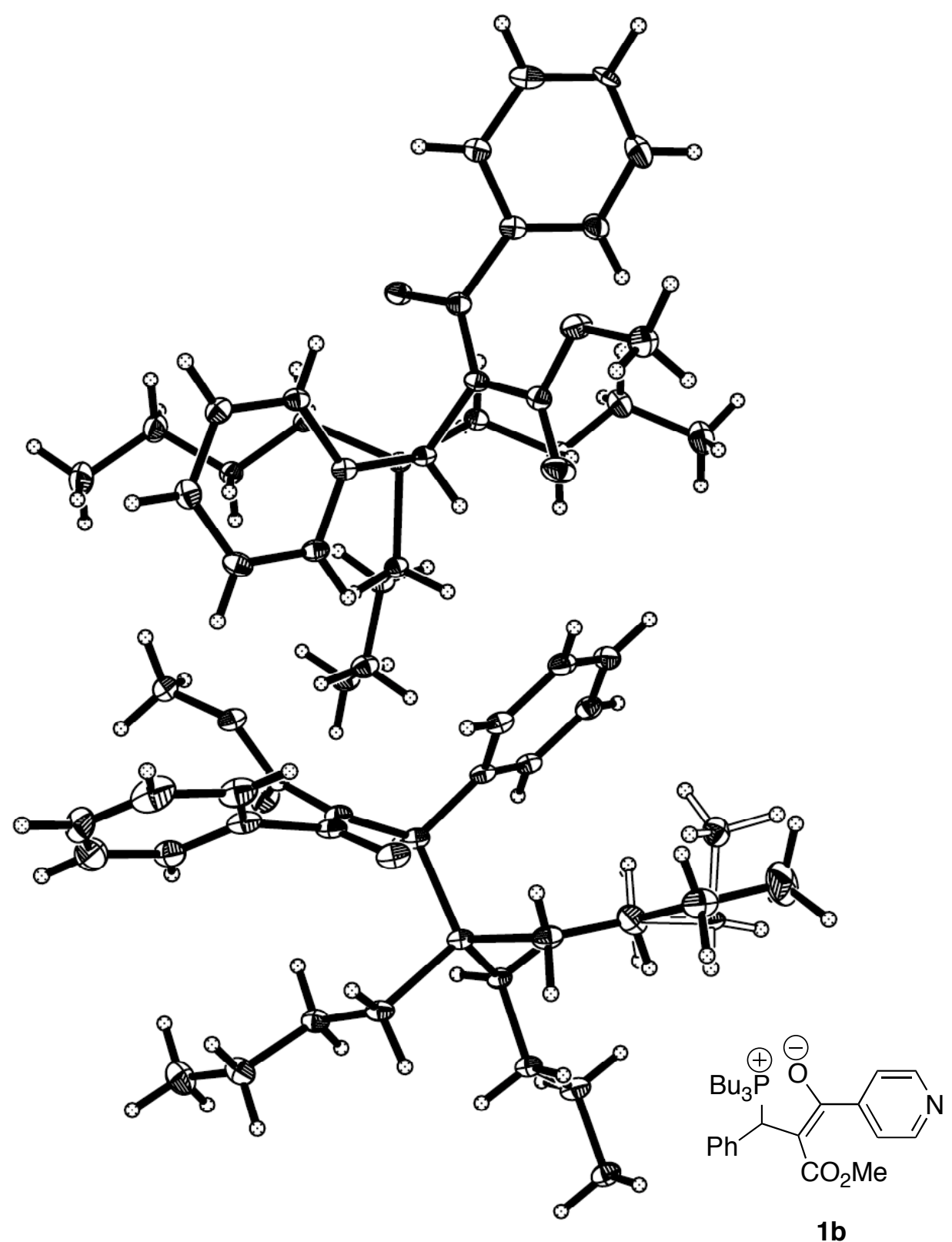


The water molecule in the X-ray structure for compound 1f presumably arose from the presence of adventitious water molecules in the solvent.
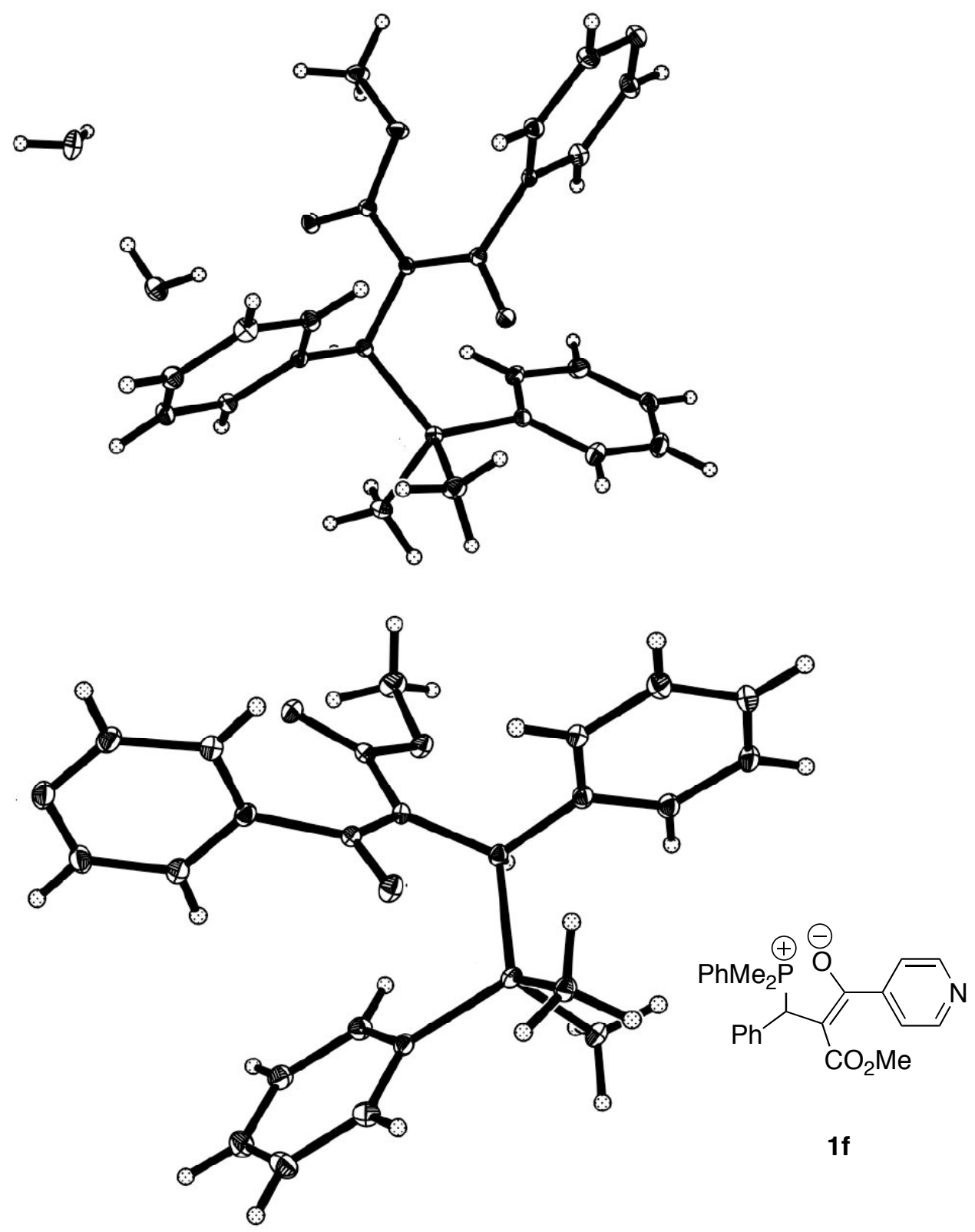